\title{
Development of the Predict Observe Explain (POE)- based on Thematic Teaching Materials for IV Grade Students of Elementary School
}

\author{
Amalia Puspha Rini \\ Educational Technology \\ Universitas Sebelas Maret \\ Surakarta, Indonesia \\ amaliaaapr@student.uns.ac.id
}

\author{
Nunuk Suryani \\ Educational Technology \\ Universitas Sebelas Maret \\ Surakarta, Indonesia \\ nunuksuryani@staff.fkip.uns.ac.id
}

\begin{abstract}
Siti Sutarmi Fadhilah
Educational Technology

Universitas Sebelas Maret

Surakarta, Indonesia

fadh.sant@gmail.com
\end{abstract}

\begin{abstract}
The Learning process cannot be separated from the use of teaching materials that play important roles in achieving the competencies that must be achieved by the learners. The purpose of this research is to identify the importance of the development of thematic teaching materials based on the Predict Observe Explain (POE) technique for the IV grade students of elementary school. This study uses the research and development method. The product development is done through the steps of the design model of ADDIE learning system, including (1) analysis, (2) design, (3) development, (4) implementation and (5) evaluation. This research is conducted within three steps, i.e. (1) analysis, (2) design and (3) development. The data collection techniques used are observation, interviews and questionnaires. The results of the POE-based thematic teaching materials have excellent quality and are appropriate to be applied for the IV grade students. This is based on the validation results from media experts, materials experts, three one-on-one learner trials, ten trials of small group participants, and twenty trials of field learners. The results are shown from the average score of the product as much as 4.37 in terms of graphics, 4.66 from the material aspect and 4.75 from the aspects of legibility, linguistic and presentation taken from the IV grade students as the product users.
\end{abstract}

Keywords - teaching materials; thematic; POE

\section{INTRODUCTION}

Education is one of the benchmarks of the development of a nation. The high-quality of human resources (HR) in a country can be correlated with the quality of good education. Therefore, a good education is required, so that Indonesia can compete, not only on a national level, but also globally.
Sumantri and Syaodih [1, 6.13] stated that elementary school (sekolah dasar/SD) is a basic level of education in Indonesia that has a very important role in efforts to improve the quality of human resources (HR). According to Buhler in [2], the stages of children development last between 9-11 years, where the children have high objectivity, and this period can also be referred as a period of investigating, trying and experimenting, stimulated by probing with great curiosity and a concentration and hoarding period for training and exploring. Based on these statements, it can be concluded that fourth grade elementary school students are at the age of 9-10 years, which also portray similar characteristics as previously stated.

Currently, Indonesia is in a transition era, from the use of curriculum called Education Unit Level Curriculum (KTSP) to Curriculum 2013. The implementation of Curriculum 2013 at the elementary level uses thematic approaches applied for class I to class VI. Because it is still relatively new, the available teaching materials are still very limited, so the development of teaching materials is very important, considering that the curriculum will be effective nationally in 2018. In fact, the success of a teacher in implementing the thematic learning depends on his/her own insight, knowledge and level of creativity in managing the materials [3, p. 180].

Besides the use of learning materials, appropriate and interesting teaching models, methods, techniques or strategies which are then implemented based on the teaching materials will also affect the interest of the learners in following the learning process. One effort that can be done to realize such learning is to design a learning source based on Predict Observe Explain (POE). POE is a learning technique 
introduced by White and Gunstone. This instructional technique is based on the constructivism learning theory, which assumes that through the activities of prediction, observation and explaining the results of observation, the cognitive structure will be formed well [4, p. 93]. This is supported by the research conducted by Nuraini, Karyanto, and Sudarisman [5], which shows that the development of POE-based modules with Roundhouse Diagram is effective and can influence science process skills (KPS) and learners' ability to explain during Biology lesson.

The use of POE-based learning materials is expected to create instructional communication, because learners obtain information or new experiences through instructional communication Heinich [6, p. 52]. Yusuf [7, p.11] explains that the benefits of instructional communication, among others, the effects of behavioural changes that occur as a result of instructional communication actions, can be controlled. Therefore, if instructional communication goes well, it is hoped that the learning objectives will be more easily achieved.

Based on the results of interviews and preliminary observations on the learning activities undertaken by the teachers and students of class IV at SD Negeri Mendala 02 and SD Negeri Mendala 01, the teaching materials used are only taken from the government. The teaching materials used are still in the form of thematic materials to support the implementation of Curriculum 2013, which up to now still require many revisions. In addition, the development of the teaching materials is still incomplete; students still struggle to understand what they have learned. Furthermore, it is also known that the learners feel confused about the teaching materials because there is no summary and exercise questions at the end of learning activities that enable a better understanding of the content.

Based on the descriptions above, the main problems/questions in this study are: (1) what is the development procedure of POE-based thematic materials? (2) how is the quality of POE thematic product-based teaching materials?

The purposes of this research are: (1) to identify the development procedure of POE-based thematic materials; (2) to identify the quality of POE thematic product-based teaching materials.

\section{REVIEW OF LITERATURE}

\section{A. Teaching Materials}

According to Dick \& Carey in [8, p. 2], teaching materials represent a set of lesson materials/ substances systematically prepared, displaying a complete figure of competence that will be mastered by the learners in the learning activities. Furthermore, the National Center for Competency Based Training [9, p. 16] states that teaching materials are all forms of materials used to assist teachers or instructors in carrying out the learning process in the classroom. The materials in question can be either written or unwritten materials.
Furthermore, Prastowo [9, p. 17] explains that teaching materials (information, media and texts) are all systematically prepared, showing the whole figure of competence that will be mastered by the learners and used in the learning process to plan and review the learning process. This is in line with the opinion of Hamdani [10, p. 20] who states that teaching materials are all forms of materials arranged systematically and used to help the teachers or instructors in carrying out teaching and learning activities to create an environment or atmosphere that allows the learners to learn well.

From some opinions above, it can be concluded that teaching materials are a set of lesson materials / substance (information, media and text) systematically prepared to help the teachers or instructors in the teaching process to help learners master certain competencies based on the goals of planning and reviewing the learning process.

\section{B. Thematic Learning}

According to Kamus Besar Bahasa Indonesia [9, p. 51], thematic is defined as "all matters related to the theme"; and the "theme" itself means "the main idea; the basis of the story (which is spoken, used as the basis of making up, altering poetry, etc.)." Furthermore, Trianto [11, p. 147] explains that thematic learning is interpreted as a learning process that is designed based on certain themes. In the discussion, the theme is viewed from various subjects. Furthermore, Daryanto [12, p. 3] argues that thematic learning is defined as a learning that uses themes to link some subjects to provide meaningful experiences to the students.

Based on some opinions above, it can be concluded that thematic learning is a learning that is designed related to certain themes viewed from various subjects with the aim to provide meaningful experience to the learners.

\section{Predict Observe Explain (POE)}

Warsono and Hariyanto [4, p. 93] define that POE is a learning technique introduced and developed by White and Gunstone. This learning technique is based on the theory of constructivism learning, which assumes that through the activities of prediction, observation and explaining the results of observation, the cognitive structure will be formed properly. This is in line with the opinion of $\mathrm{Wu} \&$ Tsai who explains that learning using the POE technique is based on constructivism learning theory, that is, by exploring the knowledge gained or possessed by the students previously interpreted.

Karamustafaoğlu [13, p. 12] explains that, "the $P O E$ strategy is an inevitable way to make science courses more interesting, to induce permanent learning and to eliminate misconceptions." The statement can be interpreted that the learning applied by using the POE technique can make the science lesson become more fun, thus, make the learning materials more embedded in the students because they get involved in the learning, and avoid or eliminate any misconception in the learning. 
Besides, according to Indrawati and Setiawan, learning using the efficient POE technique can create a good atmosphere of discussions about the concept of science, because the POE learning technique involves them predicting a phenomenon, observation through demonstration or experimentation and finally explaining the results of their previous demonstrations and forecasts.

Based on some opinions above, it can be concluded that the POE learning technique is based on the theory of learning constructivism. Learning theory is applied by exploring knowledge that has been obtained or owned by the previous students and then interpreted through some activities to predict the experiments to be performed. Furthermore, observations are made to test the correctness of predictions, and explain the results of observations that have been done, whether they fit the initial prediction or not.

\section{RESEARCH METHODS}

This study uses the Research and Development method. Gall, Gall, and Borg [14, p. 569] defined that, "Educational research and development $(R \& D)$ is a process used to develop and validate educational products. Goal of educational research is not to develop products, but rather to discover new knowledge (through basic research) or to answer specific questions about practical problems (through applied research)". Based on this statement, it could be understood that the research and development in education is a process used to develop and validate educational products and aims not to develop products, but to discover new knowledge (through basic research) or answer specific questions about practical issues (through applied research). The development procedure in this study is adapted from the model of ADDIE learning system design, i.e. (1) analysis, (2) design, (3) development, (4) implementation and (5) evaluation. However, this study was only divided into three steps. This research development started with the analysis phase, using preliminary study consisting of interviews, field observations and literature review from the latest curriculum. Furthermore, the design phase aimed to design the product based on the results of the analysis obtained. Once designed, the development was carried out to identify any weaknesses on the initial product designed through two stages: (1) expert validation and (2) trials.

The data obtained in this study were quantitative, taken from the questionnaires of expert validation, one-to-one trials, small group trials and field trials. Expert data, one-on-one trials, small group trials and field trials were used to determine the feasibility of the product. The data analysis technique used was descriptive statistical analysis. The quantitative data were then converted into qualitative one using scale 5 as follows.
TABLE I. CONVERSion Of QuANTITATIVE INTO Qualitative Data [15, P. 5]

\begin{tabular}{|c|c|c|}
\hline Interval Score & Score & Category \\
\hline $\mathrm{X}>4,21$ & 5 & Very Good \\
\hline $3,40<\mathrm{X} \leq 4,21$ & 4 & Good \\
\hline $2,60<\mathrm{X} \leq 3,40$ & 3 & Fair \\
\hline $1,79<\mathrm{X} \leq 2,60$ & 2 & Poor \\
\hline $\mathrm{X} \leq 1,79$ & 1 & Very poor \\
\hline
\end{tabular}

\section{RESULTS AND DISCUSSION}

This research is divided into three main steps, i.e. (1) analysis, (2) design and (3) development.

\section{A. Analysis}

The results of research include the analysis of the needs obtained from interviews and observations conducted on the fourth grade teachers of SD Negeri Mendala 01 and SD Negeri Mendala 02, validation of teaching materials by media and material experts and one-on-one testing on three students, a small group trial of 10 students and field trials for 20 students.

Based on the results of interviews and observations, it can be concluded that the thematic materials used are only from the government. The teachers feel that the development of materials in their teaching materials is still not yet satisfied, so the students' understanding is not deep enough. Furthermore, it is also known that the students feel confused about the teaching materials because there is no summary and exercise questions at the end of each learning activity that can be used enhance understanding.

\section{B. Design}

The product is in the form of POE-based thematic materials then designed according to expected learning objectives. Below outlines some pictures of the product that has been designed.

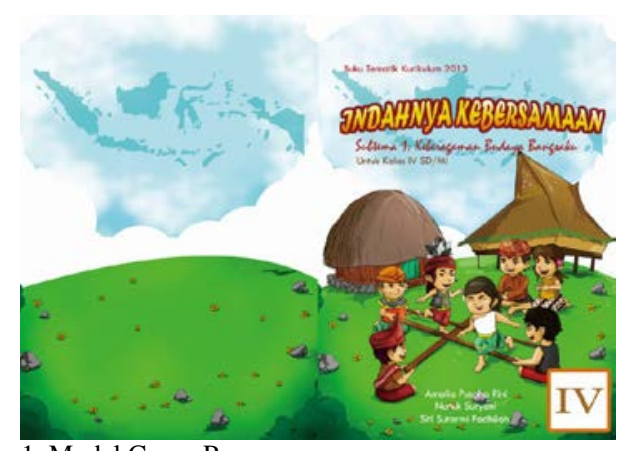

Fig. 1. Model Cover Page 


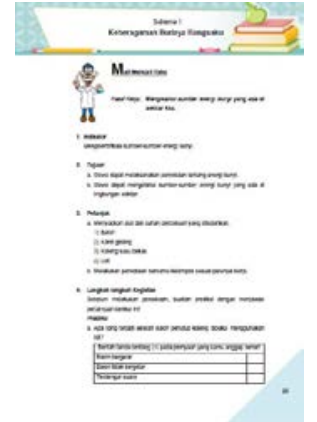

Fig. 2. Book Content

\section{Development}

Next, the initial product is developed to identify the weaknesses that exist through two stages, namely expert validation and trials.

The data from the validation of media experts, materials experts and one-on-one trial on three students, small group trial on ten students and field trials for twenty students.

TABLE II. VALIDATION RESULTS OF MEDIA AND MATERIAL EXPERTS

\begin{tabular}{|l|c|c|c|c|}
\hline \multicolumn{1}{|c|}{ Assessment } & I & II & Average & Category \\
\hline Media Expert & 4,30 & 4,44 & 4,37 & Very good \\
\hline Material Expert & 4,44 & 4,77 & 4,66 & Very good \\
\hline
\end{tabular}

Based on Table 2, it can be seen that the average score of product assessment conducted by the media experts assessing the aspect of graphic is 4.37 , and the average score of product assessment conducted by the material expert assessing the material aspect is 4.66 .

TABLE III.

CONVERSION OF QUANTITATIVE INTO QUALITATIVE DATA [15, P. 15]

\begin{tabular}{|l|c|c|}
\hline \multicolumn{1}{|c|}{ Assessment } & Average & Category \\
\hline One-on-One Trial (3 learners) & 4,84 & Very good \\
\hline Small group Trial (10 learners) & 4,61 & Very good \\
\hline Field Trial (20 learners) & 4,80 & Very good \\
\hline Average & 4,75 & Very good \\
\hline
\end{tabular}

Based on Table 3, it can be seen that the average score of product assessment from the one-to-one trial for three students is 4.84, the average score of product assessment from the small group trial for ten students is 4.61 , as well as the average score of product assessment from the field trial for twenty students is 4.80; as such, the mean of all three is 4.75 .

Therefore, it can be concluded that from the expert assessment and product trial, POE-based thematic teaching materials have excellent quality and are suitable to be applied for the IV grade students of elementary school.

\section{CONCLUSIONS AND SUGGESTIONS}

Based on the results of the research and discussions, it can be concluded that the thematic materials based on Predict Observe Explain (POE) is developed based on the analysis of the need for the availability of teaching materials that refer to the Curriculum 2013. The teaching materials are developed through the steps of the design model of ADDIE learning system, including (1) analysis, (2) design, (3) development, (4) implementation and (5) evaluation. However, this study only covers three of them.

The teaching materials developed apparently have excellent quality and are suitable to be applied for the IV grade students based on validation results from media experts, materials experts, one-on-one trial for three students, small group trial for ten participants, and field trial for twenty students. This is indicated by the average score of the product is 4.37 in terms of graphics, 4.66 from the material aspect and 4.75 from the aspects of readability, linguistics and presentation according to the users.

Based on the research conducted, the researchers provide suggestions, namely: (1) the teachers need to master adequate ability to minimize many incorrect materials found in textbooks provided by the government; (2) the schools need to provide a sufficient collection of learning sources to support the learning so that the learners can gain rich knowledge and deep understanding; (3) The Department of Education, as a government agency that directly takes care of the teachers, needs to provide opportunities and facilities to improve their professionalism through courses, training or further studies.

\section{ACKNOWLEDGMENT}

The author would like to thank to all those who have helped in carrying out this research, particularly Prof. Nunuk Suryani, M. Pd. and Dr. Siti Sutarmi Fadhilah, M. Pd., for their patience, guidance, enthusiastic encouragement and useful critiques of this research work. I would also like to thank my parents for their support and encouragement throughout my study.

\section{REFERENCES}

[1] M. Sumantri, and N. Syaodih, Perkembangan Peserta Didik [Learner's Development]. Jakarta: Universitas Terbuka, 2009.

[2] A. Sobur, General Psychology. Bandung: Pustaka Setia, 2010.

[3] Trianto, Desain Pengembangan Pembelajaran Tematik bagi Anak Usia Dini TK/RA \& Anak Usia Kelas Awal SD/MI [Thematic Learning Development Design for Early Childhood PG/RA and Early School Student Elementary School/MI]. Jakarta: Prenadamedia Grup, 2015.

[4] Warsono and Hariyanto. Pembelajaran Aktif: Teori dan Asesmen [Active Learning: Theory and Assessment]. Bandung: PT Remaja Rosdakarya, 2012.

[5] N. Nuraini, P. Karyanto, and S. Sudarisman, "Pengembangan Modul Berbasis POE (Predict, Observe, and Explain) Disertai Roundhouse Diagram untuk Memberdayakan Keterampilan Proses Sains dan Kemampuan Menjelaskan Siswa Kelas X SMA Negeri 5 Surakarta (Penelitian dan Pengembangan Materi Pencemaran Lingkungan Tahun Pelajaran 2013/2014) [Development of POE-based (Predict, Observe, and Explain) Module accompanied by Roundhouse Diagram to Empower Sains Progress Skill and Explaining Ability of $10^{\text {th }}$ Grade Student of State Senior High School 5 Surakarta (Research and 
Development of the Lesson about Environmental Pollution, School Year 2013/2013],” Bioedukasi: Jurn. Pend. Bio., vol. 7, no. 1, pp. 37-43, 2014. [Online]. Available: https://jurnal.uns.ac.id. [Accessed Jul. 23, 2017].

[6] Suparno, "Kemahiran Berkomunikasi Lisan dalam Konteks Instruksional Guru Sekolah Dasar, [Oral Communication Proficiency in Elementary School Teacher Instructional Context]” Jurn. Ilm. Pend., vol. 6, no. 1, 1999. [Online]. Available: http://journal.um.ac.id. [Accessed May 28, 2018].

[7] M. P. Yusuf, Komunikasi Instruksional [Instructional Communication]. Jakarta: Bumi Aksara, 2010.

[8] F. Sukmawati, "Pengembangan Bahan Ajar Biologi Berbasis Contextual Teaching Learning untuk Mengefektifkan Pembelajaran bagi Siswa SMA [Development of Contextual-Teaching-Learning-based Biology Teaching Material to Make the Learning Progress for High School Student Effective],” Fenomena, vol. 7, no. 1, 2015. [Online]. Available: http://journal.iain-samarinda.ac.id. [Accessed Jun. 29, 2017].

[9] A. Prastowo, Pengembangan Bahan Ajar Tematik: Tinjauan Teoretis dan Praktis [Development of Thematic Teaching Materials: Theoretical and Practical Review]. Jakarta: Kencana Prenadamedia Group, 2014.

[10] Hamdani, Strategi Belajar Mengajar [Learning and Teaching Strategy]. Bandung: CV Pustaka Setia, 2010.
[11] Trianto, Desain Pengembangan Pembelajaran Tematik bagi Anak Usia Dini TK/RA \& Anak Usia Kelas Awal SD/MI [Thematic Learning Development Design for Early Childhood PG/RA and Early School Student Elementary School/MI]. Jakarta: Kencana Prenada Media Group, 2011.

[12] Daryanto, Pembelajaran Tematik, Terpadu, Terintegrasi (Kurikulum 2013) [Thematic, Coherent, and Integrated Learning (2013 Curriculum)]. Yogyakarta: Penerbit Gava Media, 2014.

[13] S. Karamustafaoğlu, "Understanding Electrochemistry Concepts using the Predict-Observe-Explain Strategy,” Eurasia J. of Maths., Sci. and Technol. Edu., vol. 11, no. 5, pp. 923-936, 2015. [Online]. Available: www.ejmste.com. [Accessed Aug. 24, 2017].

[14] M. D. Gall, J. P. Gall, and W. R. Borg, Educational Research: An Introduction, 7th Ed. New York: Pearson Education Inc, 2003.

[15] Y. S. Maharani, N. Suryani, and D. T. Ardianto, "Pengembangan Multimedia Pembelajaran Interaktif pada Mata Pelajaran Pengolahan Citra Digital di Sekolah Menengah Kejuruan Negeri 8 Semarang [Multimedia Interactive Learning Development of Digital Image Subjects at State Vocational High School 8 Semarang],” Prosiding Seminar Nasional Teknologi Pendidikan, 2017. [Online]. Available: http://www.jurnal.fkip.uns.ac.id. [Accessed Jan. 31, 2018]. 